\title{
Memória histórica de 1948
}

\author{
A. Almeida Júnior \\ Catedrático de Medicina Legal na Faculdade de \\ Direito da Universidade de São Pa.ulo.
}

\section{Introdução}

Foram os Estatutos de 1854, de Couto Ferraz, que instituiram nas Faculdades de Direito do Império a "Memória histórica", a ser escrita cada ano por um lente da Casa, designado pela Congregação. Devia o documento conter duas partes: uma referente aos acontecimentos notáveis do ano; outra, sôbre o grau de desenvolvimento a que fôsse levada, no período, a exposição das doutrinas do curso. Fiel ao título, o relato do professor, uma vez lido e aprovado pela Congregação, seria "recolhido à Biblioteca para servir de crônica da Faculdade". Mas o Regulamento de 1855 ampliou êsse propósito, mandando que o documento fôsse copiado ou impresso, e distribuído aos lentes das duas Faculdades. Inaugurava-se assim o intercâmbio cultural (como dizemos hoje) entre o Norte e o Sul; e, de fato, nas Memórias históricas de São Paulo vemos frequentes alusões às do Recife, ou vice-versa. Das Reformas republicanas, as duas últimas a mencionar a Memória histórica (a de Gonçalves Ferreira, em 1896, e a de Epitácio Pessoa, em 1901) foram autoritárias e restritivas: tornaram obrigatória a aceitação do encargo de redator do documento, e proibiram que neste se criticassem os atos do Govêrno em geral, ou os da Diretoria relativos à parte econômica. Mas como! - pergunta Dário Ribeiro na Memória histórica de 1908-1909. Mas como! - "se a crítica é a alma da história!" E, juntando ao preceito o ato, censura o 
citado mestre o Govêrno anterior, responsável pela famıgerada Reforma Rivadávia.

Depois da Reforma Epitácio (1901), nenhuma outra lei federal cuidou da Memória histórica. Esta apareceu, mesmo assim, no Regimento Interno da Faculdade de junho de 1915, e no de março de 1929. E foi só. Dai por diante não se falou mais nela, nem no Regulamento de 1935, baixado por Armando de Salles Oliveira, nem no de 1937, convertido em lei pela Assembléia Estadual e vigente até o dia de hoje.

A primeira Memória histórica de nossa Faculdade devia ter sido a de 1855, e supõe-se que Veiga Cabral a tenha escrito, resumindo a vida do instituto desde a sua fundação. Mas Spencer Vampré, que conta isso, não pôde encontrar o precioso trabalho. De minha parte, das 75 Memórias históricas que teòricamente se haveriam produzido entre 1855 e 1930 (se não tivessem ocorrido falhas), consegui localizar apenas 21. As falhas são grandes, mórmente depois de 1878. Com referência ao século presente, sỏ encontrei a Memória histórica de 1908-1909, de Dário Ribeiro - suponho que a última que se escreveu.

No fim do ano de 1948, o prof. Ernesto Leme, paulista de velha cepa, e que por isso se sente no dever de estudar e de estimular o estudo das nossas tradições, propôs à douta Congregação da Faculdade de Direito de São Paulo a ressurreição da crônica instituída em 1854. E sugeriu (ai de mim!) fôsse eu, na qualidade de professor mais moderno da casa, encarregado de escrever a Memória histórica do período que então se encerrava. Passados nove anos - nove anos atribulados, que me levaram a esquecer a incumbência - voltou ao assunto o prof. Ernesto Leme, embora de maneira indireta, como compete a quem, como êle, já andou pela diplomacia. Tive que render-me, e aqui apresento afinal o meu trabalho.

A exemplo de Dário Ribeiro, entendo que uma Meinória histórica sem crítica é um documento sem alma. Ouso por isso comentar com franqueza alguns fatos que narro. 
E, como nesta matéria cada qual tem o seu ponto de vista, e seria ambição demasiada pretender que a douta Congregação paulista aprovasse tôdas as minhas apreciações, sugiro que, como no passado, a aprovação, que porventura se dê a êste trabalho, alcance apenas a objetividade dos fatos, ou, então, como se dizia outrora - "a sua parte histórica".

\section{Administração e corpo docente}

Diretoria e c.T.A. - Foi diretor da Faculdade, durante o período de 1948, o saudoso prof. Gabriel de Rezende Filho; e vice-diretor, o prof. Alvino Ferreira Lima. O Conselho Técnico-Administrativo teve a seguinte composição: profs. A. de Sampaio Dória, Alvino Ferreira Lima, Braz de Sousa Arruda, Noé Azevedo, J. J. Cardozo de Mello Neto e Basileu Garcia.

CORPO DOCENTE - Assim se distribuiram os professôres pelas cinco séries do curso:

$1^{\circ}$ ano - 1) Introdução à Ciência do Direito, prof. Miguel Reale, em substituição ao prof. Spencer Vampré, afastado para tratamento da saude; 2) Economia Política, prof. J. J. Cardozo de Mello Neto; 3) Direito Romano, prof. Alexandre Correia; 4) Direito Civil, prof. Vicente Ráo; 5) Teoria Geral do Estado, livre-docente Cândido Mota Filho, substituindo o prof. J. C. Ataliba Nogueira, eleito deputado federal.

$2 .^{\circ}$ ano - 1) Direito Civil, prof. Lino Leme; 2) Direito Penal, prof. J. Soares de Mello; 3) Direito Constitucional, livre-docente M. F. Pinto Pereira, contratado; 4) Direito Comercial, prof. Soares de Faria, substituindo o prof. Honório Monteiro, que a princípio exerceu o mandato de deputado federal e, depois, o cargo de Ministro do Trabalho; 5) Ciência das Finanças, prof. Theotônio Monteiro de Barros. 
3..$^{\circ}$ ano - 1) Direito Civil, prof. Jorge Americano; 2) Direito Penal, prof. Basileu Garcia; 3) Direito Comercial, prof. Waldemar Ferreira, substituido a partir cie junho, por motivo de licença, pelo livre docente Sílvio Marcondes; 4) Direito Judiciário Civil, prof. B. de Siqueira Ferreira; 5) Legislação Social, prof. A. F. Cesarino Junior.

4..$^{\circ}$ ano - 1) Direito Civil, prof. Alvino Ferreira Lima; 2) Direito Comercial, prof. Ernesto Leme; 3) Direito Judiciário Civil, prof. Gabriel de Rezende Filho; 4) Direito Internacional Público, prof. Braz de Sousa Arruda; 5) Medicina Legal, prof. A. F. de Almeida Júnior; 6) Direito Penal, prof. Noé Azevedo.

$5^{\circ}$ ano - 1) Direito Judiciário Civil - prof. S. Soares de Faria; 2) Direito Judiciário Penal, prof. J. Canuto Mendes de Almeida; 3) Direito Internacional Privado, livre docente Luiz Antônio da Gama e Silva, em substituição ao prof. A. de Sampaio Dória, licenciado; 4) Direito Administrativo e Ciência da Administração, prof. Mário Masagão; 5) Filosofia do Direito, prof. Miguel Reale.

Não mencionamos, em relação às diferentes séries, as substituições de curta duração.

Cadeira de Direito Constitucional - Por motivos políticos fáceis de entender, o decreto-lei n. 2.639, de 27 de setembro de 1940, desdobrara a disciplina "Direito Público Constitucional" em duas, a saber: Teoria Geral do Estado e Direito Constitucional. Visto que o ensino desta última disciplina interessava vivamente aos homens do Estado Novo, autores da Carta de 10 de novembro, o referido decreto-lei transferiu compulsòriamente o titular da cadeira antiga para a nova, ficando desta forma desocupada aquela - a de Direito Constitucional — que nos três anos subsequentes deveria ser provida em caráter interino, ou mediante contrato. Passou, pois, o prof. Ataliba Nogueira a reger o ensino de Teoria Geral do Estado, sendo contratado o 
livre-docente Cândido Mota Filho para o Direito Constitucional. E icontratado por estcolha da Congregação, pois que, em virtude de feliz inadvertência do legislador de 1940, o decreto-lei n. 2.639 não atingiu essa prerrogativa daquêle órgão da Faculdade. Posteriormente, sobrevindo a desistência do livre-docente Mota Filho, ocupou o lugar, ainda como contratado, o livre-docente Manoel Francisco Pinto Pereira. Em 1947, já restaurada a legalidade, a Congregação decidiu, por maioria de votos, com base no art. 30 das Disposições transitórias da Constituição do Estado, propôr ao Govêrno, por intermédio do Conselho Universitário, a efetivação do livre docente na mencionada cadeira. Finalmente, em 6-7-1948, mediante parecer do Conselho Universitário, foi o livre-docente Pinto Pereira considerado estável como servidor público, nos têrmos da apostila do Governador em seu título.

À vista da solução oficial, entendeu a Congregação que a cadeira de Direito Constitucional estava vaga e resolveu, portanto, colocá-la em concurso, depois de ouvido o seu antigo titular, prof. Ataliba Nogueira. E com isto se chegou ao fim do ano. O concurso só se realizaria três anos depois, em 1951.

Livres-bocentes - $O$ corpo de livres-docentes, que compreendia, até novembro, vinte e um elementos, passou a contar vinte e dois a partir do referido mês, pela admissão, no respectivo quadro, da bacharel Esther de Figueiredo Ferraz, aprovada em Direito Penal. O concurso correspondente, realizado de 16 a 20 de novembro, merece comentário especial.

A candidata inscrevera-se no ano anterior, apresentando para isso a necessária tese, cujo assunto era - "A co-delinquência no moderno direito penal brasileiro." Contudo, por motivos que expôs em carta à Congregação, foi ela obrigada a desistir, antes de chamada às provas. Nessa oportunidade consultou sôbre se poderia usar, em 
subsequente inscrição, à mesma tese. Deferido ao c. T. A. o exame da matéria, deixou êste de se pronunciar, pois a própria candidata resolveu, por si, escrever nova dissertação. Outra particularidade do concurso foi a substituição de um examinador - o prof. Basileu Garcia — impedido por luto quando já julgados os títulos da candidata e realizada a prova escrita. Finalmente, como circunstância relevante, — "the last but not the least" - a candidata foi a primeira representante do sexo feminino (e por enquanto a única) a vir pleitear um lugar no corpo docente da velha Academia de São Paulo.

Ao ingressar como aluna no curso jurídico, a doutora Esther de Figueiredo Ferraz trouxera consigo uma sólida bagagem de cultura geral, mais vasta e mais profunda do que a da grande maioria dos calouros. Havia sido, antes, estudante distinta de escola secundária, de instituto de educação e de faculdade de filosofia. Não teve dificuldade, portanto, em manter o primeiro lugar entre os seus colegas, desde o concurso vestibular até o quinto ano, e em 'conquistar todos os prêmios da Academia. Por fim, ao disputar a livre-docência, seu nome de advogada já estava consagrado nos pretórios da justiça, inclusive no Tribunal do Júri. Sua tese versou sôbre "Os delitos qualificados pelo resultado"; na prova escrita tratou "Da natureza jurídica da ação exclusivamente privada", e a aula com que demonstrou sua capacidade didática, foi sôbre "As doenças mentais e outras anomalias".

A comissão examinadora, constituída pelos profs. Noé Azevedo, J. Soares de Mello, J. C. Mendes de Almeida, Siqueira Ferreira e Almeida Júnior (êste último convocado em substituição ao prof. Basileu Garcia), habilitou por unanimidade a candidata, tendo sido o seu parecer adotado pela Congregação, também por unanimidade.

Outro concurso para a livre docência - o de Direito Administrativo - não produziu resultado, por desistência do candidato. 
Bibliografia dos professôres em 1948

Damos a seguir, em relação que supomos incompleta, a produção bibliográfica dos professôres e livres-docentes: da Faculdade, durante o ano de 1948. Seguimos, na enumeração, a ordem de antiguidade dos autores, na cátedra ou na livre docência. Os trabalhos a respeito dos quais não conste indicação, foram publicados na Revista da: Faculdade de Direito da Universidade de São Paulo, vol. XVIII, 1948.

J. J. Cardozo de Mello Neto - Francisco de Paula Rodrigues Alves.

Francisco Morato - A Técnica.

Waldemar Ferreira - O Conteúdo Econômico da Constituição Brasileira de 1946.

Idem - O Jubileu Magistral do prof. Reynaldo Porchat.

Ernesto Leme - Brasilio Machado e a Academia.

B. de Siqueira Ferreira - "Conscientia duce, comite scientia" (discurso de paraninfo).

Idem - Francisco Morato, Jurista e Professor.

Miguel Reale - A Doutrina de Kant no Brasil (conclusão).

Theotônio Monteiro de Barros - Emenda ao Orçamento.

A. Almeida Júnior - Lições de Medicina Legal, $1 .^{a}$ ed., 520 págs. Comp. Editôra Nacional, São Paulo. (Assinalo que, depois de 57 anos de funcionamento da cátedra, foi êste o primeiro compêndio que teve).

Idem - Relatório da Comissão de Diretrizes e Bases da Educação Nacional, publ. oficial do Ministério da Educação.

José Dalmo Fairbanks Belfort de Mattos (livre-docente),

- Sugestões para a reforma do Código do Ar. 
Esther de Figueiredo Ferraz (livre-docente) - Os delitos qualificados pelo resultado, tese de concurso.

\section{Corpo discente}

Dados estatísticos - O total de matriculados, em 1948, foi de 1.269 alunos, assim distribuídos: $10^{\circ}$ ano, $256 ; 2 .^{\circ}$ ano, $295 ; 3 .^{\circ}$ ano, $288 ; 4 .^{\circ}$ ano, $137 ; 5 .^{\circ}$ ano, 293 . Do total de alunos, 102 ou $(8,0 \%)$ eram do sexo feminino, mostrando-se a representação dêste sexo, salvo no $3 .^{\circ}$ ano, tanto maior quanto mais recente a turma: $34(13,2 \%)$ no $10^{\circ}$ ano; $23(7,8 \%)$ no $2 .^{\circ}$ ano; $28(9,7 \%)$ no $3 .^{\circ}$ ano; $6(4,3 \%$ no $4 .^{\circ}$ ano; $11(3,7 \%)$ no $5 .^{\circ}$ ano.

Grau DE ASSiduidade - Foram pouco assíduos às aulas os estudantes de 1948; tanto que em quase tôdas as cadeiras, conforme se apurou no fim do ano letivo, mais de $50 \%$ haviam excedido o número de 19 faltas tolerado pelo Regulamento para a prestação de exames. Na cadeira que teve apenas 28 lições numa turma e 22 na outra, a proporção dos que perderam o ano por faltas subiu a $64 \%$. Isto equivale a dizer que $64 \%$ dos alunos dessas duas turmas compareceram, no máximo, a 8 aulas durante o ano. Foi uma espécie de retôrno ao regime da frequência livre, que vigorou entre 1879 e 1895 , e que tão maus resultados produziu, conforme demonstramos em trabalho publicado em 1956.

A LEI DA FREQUÊNCIA - A propósito da frequência, note-se que a lei a prestigia de tal forma que, mesmo quando consiga "fechar média" com seus exames parciais, o aluno que perdeu o ano por faltas não pode ser promovido. O assunto foi longamente estudado em 1948 pelo prof. Sampaio Dória, em parecer apresentado ao c. T. A. e à Congregação. Recordou Sua Exa. a Lei n. ${ }^{\circ}$ 7, de 19-12-46, que diz: 
Art. $20^{\circ}$ - Para poder ser promovido, o aluno, além de satisfazer às demais exigências regulamentares e regimentais, prestará, nas épocas fixadas em lei, duas provas parciais e uma prova final.

Parágrafo $10^{\circ}-\mathrm{A}$ média igual ou superior a sete (7), nas provas parciais, isenta o aluno de prova final.

Dois são, portanto, no texto do artigo (notou o prof. Sampaio Dória), os requisitos básicos para a promoção: $\left.1^{\circ}{ }^{\circ}\right)$ a satisfação às exigências regulamentares ou regimentais; $2^{\circ}$ ) a prestação de exames. E a média igual ou superior a sete, referida no parágrafo $1 .^{\circ}$, isenta o aluno tão sòmente da prestação de prova final, mas não de satisfazer às outras exigências - entre as quais, conforme o art. 103 do Regulamento da Faculdade, está a da frequência, permitidas no máximo 19 faltas.

Pronunciamento de igual data, do prof. J. Canuto Mendes de Almeida, conclui, é verdade, de maneira oposta, visto entender o eminente mestre, em sua interpretação, que "estão dispensados de frequência, por lei, os alunos que obtiverem média sete nas provas escritas". Discutida a matéria em Congregação, pediu vista de ambos os documentos o saudoso prof. Soares de Faria, cuja benignidade para com os estudantes já se havia tornado proverbial. Pois Sua Exa. reapareceu na sessão seguinte, declarando que estava inteiramente de acôrdo com o parecer do prof. Sampaio Dória. E êste parecer recebeu imediata e unânime aprovação do corpo de professôres.

Disciplina - Venho tendo contacto, desde 1929, com os estudantes da nossa velha Academia, e dêles posso ainda hoje repetir aquilo que disse no meu discurso de posse de catedrático, em dezembro de 1941: - "são incomparàvelmente mais estudiosos do que o admite a fama, e perfeitos nas aulas" - excetuado o caso endêmico (que ressalvei) 
"de dois ou três dorminhocos inofensivos" - vítimas, talvez, de tresnoites habituais, a que se junta a monotonia da preleção. Se fôssem outras as condições da nossa Faculdade, hoje imensamente atingida pela pletora (que tanto prejudica o aperfeiçoamento didático de qualquer escola), estou convencido de que o conhecimento mais íntimo, que então poderiamos travar com os alunos, melhoraria muito o conceito que dêles se faz. A grande maioria é excelente, ao menos no que diz respeito à moralidade; e em seu seio se destacam moços de elevada inteligência e sólida cultura.

O mal está em juntar-se quase todos os anos, na Faculdade de Direito (e talvez em outros institutos), um pequeno grupo de jovens diferentes dos outros - aberrantes de maneiras, turbulentos, inimigos da disciplina, destituídos de curiosidade intelectual, omissos nas salas de aula, avezados à fraude ou reincidentes nas reprovações - e que, segundo parece, ingressam no cursso superior menos por desejo de cultivar-se do que para poderem, sob a carinhosa imunidade que a tradição concede aos estudantes, dar vazão aos seus instintos agressivos ou predatórios. São êles os iniciadores na brutalidade do trote, os depredadores dos móveis do estabelecimento, os voluntários da tropa de choque nas greves imotivadas. Foram êles os que, durante anos sucessivos, tentaram converter em espetáculo de circo a cerimônia da colação de grau. É é em tôrno dêles que se organiza o assalto aos restaurantes, bares e confeitarias - a criminosa "pindura" com que maltas de vagabundos, na quase totalidade estranhos à família acadêmica, maculam as festividades do dia 11 de agôsto. Não passam, talvez, perigosa. Mas, por sua audácia e truculência, impressionam - quando não arrastam os colegas ingênuos, para de um por cento da matrícula os integrantes dessa "gang" os quais "isso é que é tradição. ." O ruido exterior, que produzem, chama a atenção dos transeuntes e, fazendo crêr que se trata de loucura coletiva, já levou a imprensa a dizer que "é preciso fechar a Faculdade de Direito". 
Em verdade, essa medida radical nunca se tornou necessária - porque a doença, felizmente, só atinge a uma insignificante minoria. Se professôres e funcionários pudessem ir assinalando em cada turma, desde o primeiro ano, os elementos que, por defeitos de personalidade, erros de educação ou repugnância pelo estudo, não se ajustam devidamente à comunidade escolar, e ameaçam constituir-se em agentes crônicos da indisciplina, seriam evitados, por certo, inúmeros aborrecimentos à administração da Faculdade. Uma vêz identificados aquêles elementos, procurar-se-ia aplicar, a cada caso, a terapêutica adequada, no propósito de corrigir os desvios de conduta. E, quando se visse que o mal era incurável, recorrer-se-ia à segregação definitiva, único meio de resguardar a saúde moral do instituto.

Em 1948, na véspera do aniversário da Academia, o presidente do Centro Acadêmico declarou, através, de comunicado à imprensa, que a agremiação não se responsabilizaria pelos prejuizos do comércio, "quase invariàvelmente causados por elementos estranhos à classe acadêmica". Como efeito prático, a advertência não logrou senão acautelar um pouco as vítimas ameaçadas e deixar em suspenso a acusação contra a Academia. Valeu, entretanto, de qualquer forma, como princípio de reação. Pena é que a previsão do presidente não tenha alcançado o feio episódio de poucas semanas mais tarde, em que foram furtados, no Parque da Água Branca, perús de raça da Exposição Nacional de Animais, os quais, no dizer de importante órgão da imprensa, serviram aos estudantes (?) "para um regabofe ao ar livre". "Estudantada ou vandalismo?" - perguntou então o jornal (8-10-48). Fique a resposta ao arbítrio de cada um.

Durante o ano, muito próximo ainda do período confuso da ditadura, assistimos a várias manifestações de acadêmicos, perturbadoras da disciplina. Daí algumas punições mais ou menos benígnas, aplicadas pelos órgãos 
competentes, e cujos atos processuais invadiram o ano subsequente.

\section{A Biblioteca e sua estatística}

A Biblioteca da Faculdade de Direito (a mais rica na especialidade, entre as da América do Sul) ficou aberta em 270 dias durante o ano, e teve, nesse periodo, 14.706 consultas por parte de alunos do estabelecimento. Se todos êsses leitores foram estudantes da casa, o número de consultas dos alunos matriculados em 1948 equivaleu a onze (11) para cada um. Ora, no triênio 1908-1910, êsse quociente, como assinalamos ("Problemas do Ensino Superior", pag. 182) foi de cinco (5); permitindo concluir que a frequência à Biblioteca melhorara, de então para 1948. Contudo, já havia sido bem superior no triênio 1939-1941, em que chegou a quinze consultas por aluno.

De que assuntos tratavam as $\mathbf{1 4 . 7 0 6}$ obras consultadas? Principalmente de Ciências Sociais e Jurídicas (quase 80\%); vindo a seguir, por ordem decrescente: Obras gerais, Literatura, Filosofia, Ciências aplicadas, História e Geografia, Filologia. As Ciências puras só tiveram 31 consulentes durante o ano; a Religião, só 5; as Belas Artes, também só 5 .

A língua mais lida foi a portuguêsa $(70 \%$ das obras consultadas). Aparecem depois, ainda em ordem decrescente, o francês, o italiano, o espanhol, o latim. Em último lugar ficou o inglês, apesar de relativamente rica a Biblioteca em livros nessa língua. Das duas uma: ou o nosso estudante de direito, apesar da preferência que dá, em vestibular, ao Inglês, não se sente capaz de estudar nessa língua, ou então não o interessa muito o direito inglês ou norte-americano.

\section{Trabalhos letivos e exames}

Exames vestibulares - Efetuado em fevereiro o concurso vestibular para preenchimento de 200 vagas, foram 
habilitados 185 dos :363 inscritos (reprovados 49,1\%). Restando 15 vagas na $1 .^{\mathrm{a}}$ série, entendeu conveniente o c. T. A. que, nos têrmos do Decreto-lei n. 9.154, de 8-4-1946, se abrisse nova inscrição para um segundo concurso. Dos 108 candidatos que então se inscreveram, 55 foram aprovados (reprovados 49,1\%). Decidiu o c. T. A., ainda, que se admitissem à matrícula os 240 candidatos aprovados, divididos em duas turmas, como já se vinha fazendo desde 1935.

Breve inquérito efetuado em abril, e que abrangeu 74 dêsses novos alunos, permitiu apurar, entre outros, os seguintes informes a respeito dêles: 1) idade - menores de 21 anos, $58 \%$; de 21 a 24 anos, $32 \%$; de 25 anos para mais, $10 \%$; 2) estado civil - solteiros, $96 \%$; casados, com filhos, $3 \%$; casados, sem filhos, $1 \%$; 3) nacionalidade brasileiros, $99 \%$; estrangeiros, $1 \%$; 4) lugar de nascimento — Estado de São Paulo, 88\%; outros Estados, 11\%; Estrangeiro, $1 \%$; - 5) residência - com a família, $73 \%$; em pensão, $15 \%$; outras formas, $12 \%$; 6) manutenção no estudo - assegurada pelos pais, $62 \%$; pelo trabalho, $18 \%$; pelos pais e pelo trabalho, $18 \%$; por outros e pelo trabalho, $1 \%$; não informou, $1 \%$; 7) profissão dos pais profissão liberal, $28 \%$; funcionário público, $23 \%$; comércio, $22 \%$; agricultura, $5 \%$; indústria, $3 \%$; outras profissões, $10 \%$; não informaram, $9 \%$. Êstes dados terão maior interêsse quando fôr possível confrontá-los com outros, de épocas diferentes.

Aula inaugural - A aula inaugural dos cursos foi proferida em 15 de março, pelo professor emérito Francisco Morato. O grande mestre de Direito Judiciário Civil -. que iria falecer daí a dois meses - estava então com oitenta anos, e, dez anos antes, fôra aposentado por implemento de idade. Na véspera da aula inaugural veio à Faculdade examinar a sala em que falaria. Escolheu o salão de festas destinado às grandes solenidades: será. 
(escrevera êle antecipadamente) "a segunda das lições que se prelecionam neste salão nobre, nesta Magna Aula, inaugurada na data aniversária da fundação dos Cursos Jurídicos, a 11 de agôsto último..." Mas não foi no salão nobre. No dia seguinte preferiu o mestre a sala "João Mendes", mais acessivel, mais singela e de melhor acústica.

O assunto escolhido foi "A Técnica". "Que é o que é a técnica?" - perguntou. "Que é o que se há de rigorosamente chamar de técnico?" A seguir, através de sábia dissertação, chegou ao conceito final: "Do que temos exposto e do estudo aprofundado da matéria, deduz-se que, conquanto variem os ofícios ou profissões, a técnica é sempre a mesma arte: a habilidade, o jeito, a finura com que o profissional, instruído e experimentado na sua profissão, com meios e em circunstâncias adequadas, pratica a matéria de seu ofício".

Era Francisco Morato contrário (para não dizermos hostil) aos discursos lidos e não deixou de adverti-lo enfàticamente em sua lição solene, quando se referiu à decadência na técnica da Retórica: "Os discursadores e conferencistas, além da negligência da forma e da terminologia, não falam nem oram: leem - o que é um hábito vilão, contrário à natureza das coisas, repugnante às leis da Eloquência e condenado desde a mais remota antiguidade; vilão, repugnante e condenado sobretudo para os professôres. " Coerente com essa afirmação, falou êle, sem ler nem consultar qualquer nota, durante quase uma hora. Não excedeu de uma hora, de caso pensado; porque, como acreditava (e afirmou então), "não há orador ou tribuno, por mais eloquente que seja, que consiga manter a atenção do auditório por mais de uma hora".

O velho mestre falou em pé, sempre ereto, com voz firme, sublinhada por gesticulação peculiar, rígida e angulosa. Não teve vacilações, e apenas um "lapsu linguae" - - "1848" em lugar de "1948" - poderia levar-se à conta da idade. Sentou-se, afinal, sob o emocionado aplauso da 
assistência que lotava inteiramente a sala "João Mendes"; e, logo após, estando eu a seu lado, retirou do bolso a passou-me às mãos o texto original de quanto dissera, prevenindo-me: "É para o próximo número da Revista...".

Assim se despediu Francisco Morato desta Faculdade, que tanto amou, e onde durante trinta anos deu à mocidade acadêmica as melhores lições de sabedoria jurídica, juntamente com os mais altos exemplos de integridade moral. Foi êle, por seu trato afidalgado, seu estilo de sabor clássico, sua oratória, sua vasta erudição nos domínios da latinidade, seu espírito público e sua firmeza de caráter, não apenas um professor notável, mas também um grande cidadão, a evocar as mais nobres figuras do segundo Império.

Número de aulas - O desdobramento de turmas, o regime de dois concursos de habilitação (inaugurado em 1941 e tornado permanente em 1946), a facilitação das transferências (que em 1948, limitadas à $2 .^{a}$ série, elevaram, nesta, a 260 o número de alunos) a demora nos vestibulares e nos exames de segunda época, foram circunstâncias que, como de costume, impediram, em 1948, que as aulas se iniciassem a $10^{\circ}$ de março, dia marcado pela lei. Começaram "oficialmente" a 29 dêsse mês. Por isso, como também em virtude de outros motivos, estiveram elas longe de alcançar, em cada cadeira, o número máximo que o calendário escolar comporta, próximo de 75 para as cadeiras de três lições por semana, e de 150 para a de aulas diárias. Naquelas o total variou entre 22, que foi o mínimo, e 61, que foi o máximo, situando-se de regra em tôrno de 50 por turma. Nesta, de aulas diárias, alcançou a 66. Para o estudo crítico do problema, reporto-me ao trabalho que, sob o título de "Férias em demasia", já publiquei em livro. - ("Problemas do Ensino Superior").

Matéria LEcionada - Não encontrei nenhum registro da matéria lecionada nas diferentes cadeiras, nem seria 
possível obter agora, passados nove anos, que os srs. professôres preenchessem de memória aquela lacuna. Parece-me conveniente que de futuro se corrija essa falha denossa documentação didática, escriturando-se no livro de chamada, que para isso tem lugar apropriado, o assunto de cada aula.

Exames parciais E finais - Efetuaram-se com regularidade os exames parciais, escritos, de junho e de novembro. Não sucedeu a mesma coisa, entretanto, com relação aos exames finais, orais, em dezembro: tôdas as bancas. de professôres estiveram a postos nas respectivas salas, tanto em primeira como em segunda chamada (ainda havia, então, a torturante segunda chamada); mas os alunos não apareceram, impedidos de fazê-lo por determinação do Centro Acadêmico. Uma só aluna - e esta do $3^{\circ}$ ano - conseguiu da Diretoria do Centro autorização para apresentar-se a exame oral, alegando viagem ao estrangeiro, que lhe não permitiria estar de volta para a. segunda época. O motivo da greve vai exposto nesta Memória, no tópico dedicado ao abono de faltas.

Os exames só se ultimaram em fevereiro de 1949. E não podemos registrar aqui os seus resultados, matéria por matéria (como conviria), pois essa apuração não foi feita. Parece-nos de grande vantagem que se restabeleça sistemàticamente êsse tipo de tomada de contas do trabalho didático, usual outrora, e que é o único aproveitável para estudos comparativos.

Contra a fraude aCAdÊMica - Em trabalhos já publicados, sôbre a vida acadêmica brasileira, aludi à fraude na frequência e nos exames, que vicejava no século passado à sombra da complacência de mestres e funcionários. A propósito dos incidentes de 1948, deflagrados pela questão do abono, o jornal "O Estado de São Paulo", que tanto honra a imprensa nacional, colocando-se embora inteiramente ao lado da Congregação, aproveitou o ensejo 
para censurar a Faculdade por não procurar coibir aqueles vicios. "Os fatos atuais (escreveu o jornal), se alguma lição encerram, será a de livrar a tradicional escola, definitivamente, de um certo número de "facilidades" que nela sempre se verificaram". Estariam entre as "facilidades", no dizer do respeitável órgão, a compra da frequência e a escamoteação no sorteio do ponto de exame oral ("O Estado de São Paulo, 1-1-49).

Em carta ao jornal, publicada quatro dias depois, o prof. Gabriel de Rezende Filho descreveu minuciosamente as precauções postas em prática pelos professôres da casa, tendentes a prevenir as apontadas irregularidades, as quais, na pior das hipóteses, não se praticariam "de modo habitual" (Estado, 5-1-49). Em verdade, se casos ocorriam, que justificavam a advertência publicada, as cautelas mencionadas pelo saudoso diretor de 1948 generalizavam-se cada vez mais, tornando o ambiente escolar dos novos tempos muito mais sadio que o de outrora.

Releva notar, entre as medidas preventivas, a que propôs o prof. Soares de Mello, e que a Congregação aprovou em sua reunião de 5 de novembro de 1948. Sugeriu S. Exa. exigir-se do aluno do curso, no momento do exame, a apresentação de documento de identidade. A providência vinha realmente se impondo cada vêz mais, à medida que crescia o número de estudantes. Seis anos antes, por proposta minha ampliada pelo prof. Ernesto Leme, a Congregação já havia decidido recomendar aos srs. professôres a mesma precaução, tanto nos exames do curso como nas provas vestibulares (sessão de 3-3-42).

Encerramento do curso - A sessão solene de encerramento do curso de 1948 realizou-se no dia 13 de novembro, às 10 horas, no salão nobre. A preleção esteve a cargo do prof. Theotônio Monteiro de Barros Filho, que dissertou sôbre o tema - "A regulamentação do Comércio Internacional". 


\section{Solenidades, comemorações e conferências}

Das duas solenidades de 1948 , a primeira, ocorrida a 14 de janeiro, destinou-se à colação de grau dos bacharéis do ano anterior. Realizou-se no Teatro Municipal, e nela falou, na qualidade de paraninfo, o prof. Siqueira Ferreira. Foi esta a última festa de colação efetuada fora da Faculdade, pois em 8 de abril seguinte, resolveu a Congregação de Professôres que daí por diante a cerimônia se fizesse no salão nobre.

A segunda solenidade teve por objeto homenagear o prof. Honório Monteiro, nomeado Ministro do Trabalho. Deu-se a 27 de outubro e orou na oportunidade, em nome da Congregação, ainda o prof. Siqueira Ferreira. O prof. Honório Monteiro pronunciou uma conferência sôbre o tema - "Ideal Social na Democracia".

As comemorações do ano foram quatro. Na primeira - a festa tradicional de 11 de agôsto - proferiu o discurso oficial o prof. Miguel Reale que dissertou sôbre as relações entre o desenvolvimento das ciências e a evolução do direito. Duas outras solenizaram centenários de nascimento: o do Conselheiro Francisco de Paula Rodrigues Alves (1-7-48), e em que a personalidade do grande brasileiro foi estudada pelo Prof. Cardozo de Mello Neto; e o do prof. Brasílio Machado (4-9-48), tendo havido, pela manhã, inauguração do retrato do antigo catedrático de Direito Comercial, e, à noite, conferência do prof Ernesto Leme.

Também se comemorou o cinquentenário professoral de Reynaldo Porchat (23-10-48). Após a saudação do prof́. Waldemar Ferreira, respondeu o homenageado.

$\mathrm{Na}$ comemoração do trigésimo dia da morte do prof. Francisco Morato, o panegírico do mestre esteve a cargo do prof. Siqueira Ferreira.

Houve, afinal, durante o ano, cinco conferências sôbre temas jurídicos, proferidas por eminentes professôres es- 
trangeiros. Ei-las, a seguir, na ordem em que se realizaram: - 1) Francesco Carnelutti - Método e Ciência do Direito; Direito e Processo; Direito Processual Civil e Direito Processual Penal - respectivamente nos dias 28, 29 e 31 de maio; 2) Mario Rotondi - A autonomia do Direito Comercial na reforma dos Códigos e "La teoria dell'azienda nella nuova dottrina italiana", respectivamente nos dias 19 e 21 de agôsto; 3) Vicenzo Arangio Ruiz Adaptação do Direito Romano às exigências jurídicas do Império, no dia 27 de agôsto; 4) Salvador Dana Montana - A Justiça Social como princípio constitucional, em 1. ${ }^{\circ}$ de setembro; e 5) - Guido de Ruggero - Conceito de Nação, seu desenvolvimento e suas deformações, em 6 de outubro.

Registremos, por fim, neste capítulo, a homenagem que, a 16 de junho de 1948, foi prestada pela Ordem dos Advogados de Portugal ao prof. Waldemar Ferreira, quando S. Exa. ali proferiu uma conferência. A notícia da cerimônia está no Vol. XLIII da Revista da Faculdade.

\section{Episódio grave: - o abono de faltas}

GÊNeSE DE UMA REIVINDICAÇÃo - O mais ruidoso episódio acadêmico do ano foi o que resultou do pedido de abono de faltas, em novembro, pelos estudantes. Recapitulemos sumàriamente a gênese distante ou próxima do acontecimento, assim como seus lances principais.

O regime da frequência livre constituiu, ao tempo do Império, constante reivindicação dos estudantes brasileiros, os quais, para fazerem seu ponto de vista mais aceitável ao liberalismo romântico da época, lhe deram o rótulo enganador de "ensino livre". A obrigação de assistir às aulas (diziam êles) é coisa fastidiosa, inútil e obsoleta: pleiteamos por isso a sua abolição. "Estude cada um com quem quiser ." Um professor desta casa, Leôncio de Carvalho, defendeu a mesma idéia na memória histórica de 1871, 
e, quando mais tarde chegou a Ministro do Império, pôs em prática a inovação, que constituiu o núcleo da sua Reforma. Vigorou durante dezenove anos a infeliz experiência, graças à qual se despovoaram as quatro Academias do Brasil de então. Porque, na realidade, os alunos abandonaram em massa as salas de aula, as lições e os livros. "Estudar com quem quiser" traduziu-se para êles em "não estudar". E como a barreira dos exames (em que tanto confiava o reformador) se enfraqueceu ainda mais, o ensino superior brasileiro andou às portas da falência. Verificado isso, foi a frequência obrigatória restabelecida, primeiro para os cursos jurídicos (lei n. 314, de 30-101895), depois para as demais faculdades (Reforma Epitácio, de 1901). O germe da reivindicação, entretanto, não morreu, e de vêz em quando se reanima, especialmente quando os abalos políticos ou sociais sacodem o País.

Ora, o regime ditatorial em que permanecemos de maneira quase contínua de 1930 a 1945 , forneceu ambiente propício a tôdas as reivindicações acadêmicas tendentes à facilitação do curso, - desde a supressão dos exames até a abolição da frequência. No tocante a esta, já em 1934 o prof. Waldemar Ferreira, então diretor da Faculdade, assinalando o declínio na assiduidade às aulas, dizia: "contam os estudantes com a munificência de uma dispensa ministerial, à véspera dos exames, como tem acontecido". O dever de comparecer permanecia na lei; mas, qual a fôrça da lei ordinária, quando a própria Constituição fôra suprimida?

A Congregação e a Lei - A Faculdade de Direito ora se opusera à pressão da juventude, como sucedeu em 1934, 1943 e 1945; ora cedera, como em 1944 e 1946. Contudo, à medida que se reorganizava a vida constitucional, crescia no seio da corporação docente a resistência às facilitações ilegais. Em 1947 a petição de abono foi, um dia, repelida por 12 votos contra 11, para vencer dias depois, pela inversão do mesmo - "quorum". Em 1948, afinal, 
confiantes na estabilidade constitucional do País, os professôres tomaram a cautela de prevenir os estudantes, desde o princípio das aulas, de que cessara o período das concessões em matéria de frequência. Houvessem os moços escutado essa ad̉vertência, e o desagradável episó‘dio não teria ocorrido. Mas não escutaram, pois deveres mais imperiosos os chamavam à praça pública. Tanto que, no fim de outubro, publicada pela Secretaria a lista geral de faltas, verificou-se que era elevada a proporção de alunos sem frequência para a prestação de exames: $50 \%$, em média, em relação a cada cadeira. A costumeira reação não se fêz esperar, sob a forma igualmente usual de requerimento para o abono.

Por que haviam deixado os moços de comparecer às aulas? Que motivos especialíssimos os desviaram de sua obrigação fundamental, prescrita na legislação do ensino? Foram três as alegações: $1^{\circ}$ ) a greve contra o projeto Pedroso Júnior (de legalização do título de prático em farmácia) - greve deflagrada pelas Escolas de Farmácia, e a que a Faculdade de Direito entendera necessário aderir; $\left.2 .^{\circ}\right)$ as Olimpíadas Universitárias, realizadas em Curitiba em pleno período escolar - num país em que o ano dos institutos superiores orça em 120 dias letivos; $3 .^{\circ}$ ) o movimento popular em favor da exploração nacional do petróleo. Independentemente do exame dessas alegações, e admitindo mesmo, contra tôda a evidência, que elas pudessem constituir fôrça maior, capaz de justificar a deserção das aulas, resolveu a Congregação, reunida em 5 de novembro, indeferir o requerimento, com fundamento na preliminar de que faltava ao referido órgão competência para alterar a lei. A lei, no caso, era (e continua a ser) o art. 103 do Regulamento aprovado em 1937 pela Assembléia Legislativa do Estado.

Atitude do Conselho Universitário - Da decisão dos professôres houve, dias depois, recurso para o Conselho Universitário, proposto, aliás, de maneira menos regular. 
Pouco importa êste pormenor. O fato é que, sem o ponderado exame que a matéria reclamava, e por 14 votos contra 6 (abstendo-se de votar os profs. Gabriel de Rezende Filho e Ernesto Leme, respectivamente diretor da Faculdade e representante da Congregação), o Conselho Universitário concedeu o abono requerido, invalidando, assim, a decisão da Faculdade.

Isto foi a 19 de novembro. No dia seguinte reuniu-se a Congregação e designou, para estudar o assunto e propor o que parecesse acertado, uma comissã́o constituida pelos profs. Vicente Ráo, Noé Azevedo, Siqueira Ferreira e Almeida Júnior, ficando desde logo convocada, para o dia 25 , nova sessão, em que se tomaria a decisão final.

A Congregação recorre ao Ministro - Na reunião do dia 25, a comissão acima (de que tive a honra de ser o relator) apresentou o seu trabalho, concretizado em longo parecer, que a Revista da Faculdade publicou em seu número de 1948. Depois de minuciosa exposição dos fatos, entra o documento na análise da legislação, quer estadual, quer federal, em que se baseou o indeferimento do pedido dos estudantes, e mostra a completa ilegalidade do ato do Conselho Universitário. "Mandando cancelar, para o efeito da inscrição em exame final, as faltas dos alunos da Universidade (diz o parecer), o Conselho Universitário de São Paulo revogou um dispositivo legal que regula o regime escolar da Faculdade de Direito. Exorbitou com isso da sua competência. Desconheceu leis estaduais. Desatendeu a leis federais. Contrariou tendências manifestas do legislador brasileiro e da alta administração do ensino nacional. Contrariou (podemos acrescentar) os interêsses da juventude e os da sua formação cultural e profissional". Isto pôsto, e considerado ainda que, se obedecessem à decisão ilegal do Conselho, os cursos universitários paulistas incorreriam certamente nas sanções previstas pela lei federal, a comissão advertiu: “‡ a Fa- 
culdade de Direito de São Paulo, pela precedência cronológica, a primeira escola da Universidade, e representa, no Brasil, a célula-mater da cultura jurídica. Cabe-lhe, pois, o dever de apelar para o poder competente contra o desrespeito à lei e, do mesmo passo, o de resguardar das consequências dêsse desrespeito a agremiação universitária a que pertence".

Daí a proposta com que se encerrou o parecer: "Tudo considerado, a Comissão propõe que a Congregação, por intermédio da Reitoria da Universidade, recorra ao sr. Ministro da Educação e Saude, da deỉiberação do Conselho Universitário de São Paulo, de 19 do corrente, pela qual foram abonadas as faltas dos alunos desta Faculdade, dadas durante o ano letivo de 1948". Essa proposta foi aprovada por 18 votos contra 1 .

Decisão do Ministro - Finalmente, com data de 22 de dezembro de 1948, o sr. Clemente Mariani deu provimento ao recurso da Faculdade. Do seu longo despacho constam, entre outras, estas considerações: "Não há negar que os maus hábitos, implantados durante o regime ditatorial, criaram no espírito dos estudantes a impressão de que ainda seria possível a solução, por atos de benignidade, de situações ilegais. Contra essa falsa impressão, porém, vinham sendo advertidos, desde o princípio do ano, pelos professôres da Faculdade de Direito, e, em junho, por ocasião do movimento contra o projeto Pedroso Júnior, pelo próprio Ministro, em telegrama circular aos reitores, inclusive o de São Paulo. E de qualquer modo, o que não é possível é que o Conselho Universitário ou o Ministro façam tábua rasa da lei para estabelecer o regime de frequência livre onde ela o não admite."

Foi êsse, até hoje, o último movimento dos alunos desta Faculdade, em favor de medidas facilitadoras do. curso. 


\section{0 nacionalismo no ensino universitário}

Para finalizar, refira-se o elevado debate - brilhante e erudito - travado no seio da Congregação, a propósito do contrato de um professor estrangeiro. Os institutos de ensino superior de São Paulo têm tido, desdè o século passado, a colaboração valiosa de professôres das mais diversas nacionalidades - portuguêses, italianos, espanhóis, franceses, alemães, austríacos, inglêses, norte-americanos - que aqui instalaram cátedras universitárias, organizaram laboratórios de pesquisas ou lecionaram em caráter permanente, prestando com isso, à nossa cultura e formação profissional, serviços inestimáveis. No ensino jurídico, postos de parte os quatro lentes portuguêses do século passado (português, entre nós, é brasileiro!) podemos lembrar o exemplo recente de dois italianos ilustres - os profs. Tullio Ascarelli, da Universidade de Bolonha, e Enrico Tullio Liebman, da Universidade de Parma que mantiveram na Faculdade de Direito cursos de especialização, respectivamente de Direito Comercial e Direito Judiciário, com grande proveito para os que os frequentaram, tendo sido os dois eminentes juristas, em consequência, galardoados com o título de doutores honorários pela Universidade de São Paulo.

Parecia, portanto, à Congregação, em sua reunião de 8 de abril, que o contrato do prof. Caetano Sciascia, da Universidade de Camerino (Itália), para o cargo de auxiliar da cadeira de Direito Romano, proposto pelos profs. Alexandre Correia e Waldemar Ferreira, iria ser aprovado sem oposição. Tal não aconteceu, entretanto. O saudoso prof. Siqueira Ferreira, titular de Direito Judiciário Civil, tão zeloso e profundo na cátedra quão radical na defesa das teses por que se apaixonava, se insurgiu de forma veemente contra a proposta. "Entendo pernicioso, e muito, o contrato de um professor estrangeiro" - declarou o emi- 
nente mestre, referindo-se, evidentemente, ao ensino do direito. "Para mim, Direito é tradição" $\mathrm{e}$ "muito peculiar é a nossa tradição jurídica". "Foi Portugal (continuou S. Exa.) a primeira Nação européia a cristalizar o direito romano, canônico e bárbaro em um código, as "Ordenações Afonsinas", que datam de 1446 ou 1447..." Nestes 500 anos que já de então para cá decorreram, vem êsse direito genuinamente nosso se aperfeiçoando, aprimorando-se pela obra dos praxistas, pelo debate forense, pelas especulações doutrinárias, sob os influxos da consciência nacional; e de tal modo a êle nos afeiçoamos, nós, brasileiros, que aqui continuou em vigor o Código Filipino depois de ter sido revogado em Portugal". O prof. Siqueira Ferreira cita Cogliolo: "é infeliz o povo que pode adaptar-se à legislação estrangeira". "Conservemos, pois, (continua), a nossa tradição, a nossa própria cultura jurídica.." Admitia o saudoso mestre que um professor estrangeiro pronunciasse aqui algumas conferências: "Se mais como uma homenagem, do que como necessidade nossa, possamos confiar uma cátedra a um grande mestre estrangeiro para uma série de conferências ou rápidos cursos monográficos, em sua própria língua ou em idioma que domine, não me parece que a cátedra, e muito menos a do primeiro ano, que pertenceu a êsse magnífico orador, que é Reynaldo Porchat, seja o lugar adequado para se desnacionalizar o vernáculo, se abastardar o idioma, se poluir a linguagem..."

Nesse teôr, e através de longa e estudada declaração de voto, de que transcrevemos apenas uma pequena parte, argumentou o prof. Siqueira Ferreira, sem que, entretanto, conseguisse convencer a Congregação, que, por 11 votos contra 3 , entendeu conveniente contratar o jovem universitário italiano. E os excelentes resultados da colaboração do prof. Caetano Sciacia mostraram o acêrto dessa decisão final. 


\section{Conclusão}

Chegado o fim, convém resumir. Foi 1948 um ano difícil, quase tormentoso. Os trabalhos docentes tiveram a embaraçá-lo agitações estéreis, de origem exógena; não primaram os estudantes pela assiduidade aos exercícios escolares; os exames se procrastinaram por um conflito de atitudes entre a Faculdade e o Conselho Universitário. Ano de crises, portanto. Nem por isso deixou de haver saldo a favor do instituto. Frustrou-se uma improcedente reivindicação dos alunos, contrária à lei; e foi tão salutar a reação, que hoje, transcorridos nove anos sem reiteração da tentativa, pode-se admitir que em 1948 se encerrou o longo ciclo de movimentos juvenis, vindos desde o Império, tendentes a obter facilidades escolares; e que, por seu lado, a comunidade acadêmica principiou a compreender a importante função construtiva que lhe cabe no aprimoramento das atividades universitárias.

Lá fora, as fôrças políticas prosseguiam em sua tarefa de consolidar o regime legal. Aqui dentro, refletindo a evolução externa, reagíamos contra pressões opostas - de cima e de baixo - e lutávamos pela nossa constitucionalização interior, pelo restabelecimento definitivo da ordem, da disciplina e da seriedade na vida escolar — condições imprescindiveis ao êxito de qualquer ensino.

Tal foi, em síntese, a significação do ano letivo de 1948 nesta Faculdade. 